\title{
FAKTOR MANUSIA DENGAN KEJADIAN KESAKITAN PADA MAHASISWA AKPER PEMKAB GARUT TAHUN 2016
}

\author{
${ }^{1}$ Iwan Shalahuddin, ${ }^{2}$ Dadang Purnama, $\&{ }^{3}$ Udin Rosidin \\ ${ }^{1,2,3}$ Dosen Akper Pemkab Garut
}

\begin{abstract}
Abstrak
Tujuan penelitian ini untuk mencari hubungan antara factor manusia (host) dengan kejadian kesakitan pada mahasiswa. Tinjauan teoritis yang digunakan yaitu konsep epidemiologi, konsep sehat sakit dan Study morbiditas dan disabilitas. Penelitian ini menggunakan desain analisis melalui metode kuantitatif dengan pendekatan cross sectional. Data yang tdikumpulkan berupa variabel faktor manusia (host) yaitu umur, jenis kelamin, pola makan, pola aktifitas olah raga, pola tidur malam, riwayat sakit dahulu dan keadaan sakit sekarang. Berdasarkan hasil penelitian diketahui bahwa kesakitan mahasiswa pada mahasiswa tingkat satu dalam tiga bulan terakhir adalah 50 orang dengan frekuensi sakit setiap bulan sebesar $68 \%$. Sebagian besar terjadi pada mahasiswa perempuan (60\%) dengan pola makan 1-2 kali sehari $64 \%$, tidak melakukan olah raga $(76 \%)$, pola tidur jam $9(54 \%)$, dan memiliki riwayat sakit dahulu (58\%). Beberapa variabel yang menyatakan adanya hubungan dengan kejadian sakit di Akper Pemkab Garut adalah jenis kelamin, pola makan, pola aktifitas olah raga, dan kebiasaan tidur malam. Saran yang dapat diberikan adalah peningkatan upaya pemeliharaan sarana dan prasarana dalam menunjang perilaku hidup bersih dan sehat juga upaya untuk membentuk balai kesehatan mahasiswa. Untuk peneliti lain perlu adanya penelitian lebih lanjut tentang variabel yang belum diteliti pada penelitian ini.
\end{abstract}

Kata Kunci : Angka kesakitan, faktor manusia.

\begin{abstract}
This research refers to analysis design through qualitative method in line with cross sectional. Data gathered was in the form of human factor variable (host) namely, age, gender, diet, exercises, sleep patern, previus sicknes history and present sickness. Based on the result of the research it was discovered that the first year students sickness in the last three-month period in 2014 was 50 students with monthly frequency as 68\%. The most case refered to female students (60\%) with their diet 1-2 times per day 64\%, they did not do the exercises (76\%), sleep pattern of 9 haours (54\%), previons sickness history (58\%). The result of statistical test to some variables shows that there exists relation the care of sickness at nursing Academy of Pemkab Garut refers gender, diet, exercises, and sleep pattern. Based on the findings, the vesearcher suggests that Nursing Academy of Pemkab Garut improve any infrastructure to support clean and healthy behavior. It is also suggested that this nursing academy to work together with health office of Garut Regency to establish student health center. For other researchs, it is in need of further research related to the research variable that has not been investigated in this present research.
\end{abstract}

Key Words : The case of sickness, human factors

\section{PENDAHULUAN}

Berbagai upaya yang bertujuan untuk meningkatkan kemampuan profesional tenaga keperawatan telah banyak dilakukan, satu faktor dari banyak faktor yang mempengaruhi tingkat kemampuan seorang perawat adalah pada saat pertama kali mengikuti pendidikan dalam bidang keperawatan. Upaya menghasilkan tenaga keperawatan yang profesional, handal dan sehat tersebut sebagian besar merupakan peran penting dari institusi pendidikan. 
Akademi Keperawatan Pemerintah Kabupaten Garut, sebagai salah satu institusi pendidikan formal kejuruan bidang keperawatan, ikut berperan aktif dalam menghasilkan tenaga keperawatan yang berbudi luhur, berakhlak tinggi, sehat serta mempunyai wawasan ilmu pengetahuan yang luas. Dalam upaya menghasilkan peserta didik tersebut muncul beberapa permasalahan yang spesifik sesuai dengan karakteristik yang dimiliki oleh Akademi Keperawatan sebagai tuntutan profesi keperawatan.

Melihat kenyataan yang ada di Akademi Keperawatan Pemerintah Kabupaten Garut, dari data yang ada di bagian Akademik ditemukan dalam buku catatan kesakitan mahasiswa yang berobat sekitar 20-25\% Dalam setiap semesternya mahasiswa mengalami gangguan kesehatan fisik (sakit), walaupun jumlah prosentase tidak menetap dan selalu berubah-ubah, dengan kata lain mahasiswa Akper Pemkab Garut selama mengikuti proses belajar tingkat kehadiran mencapai $75 \%$ sampai $80 \%$ dalam satu semester atau tidak lebih dari $90 \%$ sebagai syarat batas minimal untuk dapat mengikuti ujian, karena masih adanya mahasiswa yang selalu tidak hadir akibat kondisi sakit.

Berdasarkan hasil penelitian pendahuluan tentang kesakitan mahasiswa selama tiga tahun terakhir menunjukan terjadinya peningkatan kesakitan yang dialami mahasiswa, terlihat dari catatan akademik mahasiswa yang mengalami sakit pada tahun 2014 sebanyak $20 \%$ dari 240 mahasiwa (48 orang), pada tahun 2015 sebanyak $31 \%$ dari 320 (99 orang) dan pada tahun 2016 sebanyak $40 \%$ dari 380 (152 orang). Pada tiga bulan terakhir sebanyak 82 mahasiswa dengan distribusi 50 orang $(61 \%)$ tingkat I, 11 orang (14\%) tingkat II dan 21 orang (25\%) tingkat III dengan keluhan utama yang terseringnya adalah keluhan pada gangguan sistem pencernaan seperti diare dan gastritis.

Selama ini di Akper Pemkab Garut belum ada sarana pelayanan kesehatan mahasiswa dan pelayanan yang lainnya belum berjalan dengan baik. Petugas bimbingan dan penyuluhan masih dirangkap oleh dosen pembimbing atau wali tingkat. Pola pelaksanaan layanan kesehatan yang dimanfaatkan mahasiswa sangat bervarias, yaitu dengan memanfaatkan fasilitas pelayanan kesehatan yang terdekat diluar kampus diantaranya Puskesmas, Rumah Sakit dan Balai Pengobatan swasta. Apabila kita lihat dari segi pemanfaatannya, layanan bimbingan dan penyuluhan di Akademi Keperawatan Pemerintah Garut dimanfaatkan mahasiswa untuk yang mempunyai permasalahan dalam kesulitan belajar, sedangkan yang menjadi masalah adalah belum adanya sarana bimbingan dan konsultasi serta pelayanan kesehatan mahasiswa yang dapat mengatasi masalah kesehatan, sehingga tidak tergambar pola hubungan penyakit (kesakitan) yang terjadi pada mahasiswa tersebut yang ditinjau sesuai dengan teori Triad Epidemiological yang dikemukakan oleh Jhon Gordon yang dikutip Bustan, (2007) yaitu kejadian kesakitan terjadi karena adanya ketidak seimbangan antara tiga faktor antara lain faktor manusia (Host), faktor penyebab penyakit (Agent) dan faktor lingkungan (Environment). Tujuan penelitian ini adalah untuk mengetahui hubungan faktor manusia (host) dengan kejadian sakit pada mahasiswa

Akademi Keperawatan Pemerintah Kabupaten Garut pada tahun 2016 Melalui studi ini diharapkan akan memperoleh hubungan epidemiologi penyakit yang mempengaruhi tingkat pemanfaatan layanan kesehatan serta bimbingan dan penyuluhan dalam mengatasi permasalahan mahasiswa yang secara langsung atau tidak langsung akan mempengaruhi mutu lulusan. Dengan demikian dari pihak institusi akan ada upaya untuk meningkatkan penataan sarana dan prasarana yang menunjang pelayanan kesehatan, pelaksanaan program bimbingan dan penyuluhan dalam menemukan permasalahan sedini mungkin 
sehingga tidak mengganggu terhadap proses belajar mengajar secara keseluruhan.

\section{METODOLOGI PENELITIAN}

Design penelitian ini menggunakan metode yang analisis dimana penelitian diarahkan secara objektif dan sistematis untuk mendeskripsikan atau menguraikan suatu keadaan dalam suatu komunitas melalui jenis korelasional metode observasional dengan pendekatan cross sectional, dimana variabel bebas dan variabel terikat akan di kumpulkan dalam waktu yang besamaan.

Variabel-variabel yang menjadi determinan penyakit dalam penelitian ini adalah berdasarkan pada konsep teori Triangle Epidemiologis yang dikemukakan oleh John Gordon, dikutip Bustan (2010). Dari modifikasi tersebut, maka variabel yang sesuai dengan ruang lingkup penelitian ini, diantaranya: variabel terikat adalah kejadian sakit pada mahasiswa Akper Pemkab Garut, variabel bebas faktor manusia berdasarkan jenis kelamin, pola makan, aktifitas olah raga, frekuensi aktifitas olah raga, aktifitas tidur, lamanya aktifitas tidur, riwayat penyakit dahulu, dan frekuensi riwayat penyakit dahulu.

\section{HASIL PENELITIAN}

Tabel 1. Karakteristik Responden

\begin{tabular}{lcc}
\hline \multicolumn{1}{c}{ Variabel } & F & $\begin{array}{c}\text { Prosentase } \\
\text { (\%) }\end{array}$ \\
\hline Jenis Kelamin: & & \\
Laki-laki & 20 & 40 \\
Perempuan & 30 & 60 \\
\hline Pola Makan: & & \\
1-2 kali sehari & 32 & 64 \\
3 kali sehari & 18 & 36 \\
\hline Aktivitas olah & & \\
Raga: & & \\
Tidak & 38 & 76 \\
Ya & 12 & 24 \\
\hline Kebiasaan & & \\
Tidur Malam: & & \\
Lebih dari jam 9 & 23 & 46 \\
Jam 9 & 27 & 54 \\
\hline
\end{tabular}

\begin{tabular}{lcc}
\hline \multicolumn{1}{c}{ Variabel } & F & $(\%)$ \\
\hline Riwayat Sakit & & \\
Dahulu: & & \\
Ya & 29 & 58 \\
Tidak & 21 & 42 \\
\hline Frekuensi Sakit & & \\
Sekarang: & & \\
Setiap Bulan & 21 & 72 \\
Tidak Setiap & 8 & 27 \\
Bulan & & \\
\hline
\end{tabular}

Analisis bivariat menggambarkan hubungan antara variabel bebas dengan variabel terikat. Variabel bebas dalam penelitian ini adalah karakteristik mahasiswa dan variabel terikatnya adalah kejadian sakit pada mahasiswa.

Berdasarkan. Hasil uji statistik dengan menggunakan nilai $\mathrm{p}$-Value pada alpha $5 \%$ terdapat adanya hubungan antara jenis kelamin $(0,011)$, pola makan $(0,003)$, pola aktifitas $(0,009)$, frekuensi melakukan olah raga $(0,034)$, Kebiasaan tidur malam $(0,002)$, Frekuensi lamanya tidur malam $(0,002)$ dan frekuensi riwayat sakit dahulu $(0,033)$ dengan kejadian sakit sekarang. Sedangkan Riwayat sakit dahulu tidak ada hubungan dengan kejadian sakit sekarang dengan $p$-Value 0,632.

Dari analisis diperoleh juga nilai jenis kelamin laki-laki $\mathrm{OR}=0,16$, artinya jenis kelamin mahasiswa laki-laki mempunyai peluang sakit 0,16 kali dibandingkan dengan perempuan; Pola makan 1-2 kali sehari niali $\mathrm{OR}=8,48$, artinya mahasiswa yang memiliki pola makan 1-2 kali/hari mempunyai peluang sakit 8,48 kali dibandingkan dengan mahasiswa yang memiliki pola makan 3 kali/hari; Pola aktivitas olah raga nilai $\mathrm{OR}=7,50$, artinya mahasiswa yang tidak melakukan olah raga mempunyai peluang sakit 7,50 kali dibandingkan dengan yang melakukan olah raga; Frekuensi melakukan olah raga nilai $\mathrm{OR}=0,11$, artinya mahasiswa yang melakukan olah raga dengan frekuensi 2-4 hari/minggu mempunyai peluang sakit 0,11 kali dibandingkan dengan yang melakukan olah raga setiap hari. 
Tabel: Analisis hubungan variabel bebas dengan variabel terikat

\begin{tabular}{|c|c|c|c|c|c|c|c|}
\hline \multirow{3}{*}{ Variabel } & \multicolumn{4}{|c|}{ Kejadian Sakit } & \multirow{3}{*}{$\begin{array}{l}\text { Jml } \\
\text { Total }\end{array}$} & \multirow{3}{*}{ OR $95 \% \mathrm{Cl}$} & \multirow{3}{*}{ p-Value } \\
\hline & \multicolumn{2}{|c|}{$\begin{array}{l}\text { Setiap } \\
\text { Bulan }\end{array}$} & \multicolumn{2}{|c|}{$\begin{array}{c}\text { Tidak Setiap } \\
\text { Bulan }\end{array}$} & & & \\
\hline & Jml & $\%$ & Jml & $\%$ & & & \\
\hline \multicolumn{8}{|l|}{ Jenis Kelamin : } \\
\hline Laki-laki & 9 & 45 & 11 & 55 & 20 & 0,16 & 0,011 \\
\hline Perempuan & 25 & 83,3 & 5 & 16,7 & 30 & $0,04-0,60$ & \\
\hline \multicolumn{8}{|l|}{ Pola Makan : } \\
\hline 1-2 kali & 27 & 84,4 & 5 & 15,6 & 32 & 8,48 & 0,003 \\
\hline 3 kali & 7 & 38,9 & 11 & 61,1 & 20 & $2,21-32,56$ & \\
\hline \multicolumn{8}{|l|}{ Pola Aktifitas: } \\
\hline Tidak & 30 & 78,9 & 8 & 21,1 & 38 & 7,50 & 0,009 \\
\hline $\mathrm{Ya}$ & 4 & 33,3 & 8 & 66,7 & 12 & $1,79-31,38$ & \\
\hline \multicolumn{8}{|l|}{ Frek. Olah Raga : } \\
\hline $2-4 \mathrm{hr} / \mathrm{mg}$ & 1 & 11,1 & 8 & 88,9 & 9 & 0,11 & 0,034 \\
\hline Setiap hari & 3 & 100 & 0 & 0 & 3 & $0,18-0,70$ & \\
\hline \multicolumn{8}{|l|}{ Kebiasaan tidur: } \\
\hline$>$ jam 9 & 10 & 43,5 & 13 & 56,5 & 23 & 0,09 & 0,002 \\
\hline Jam 9 & 24 & 88,9 & 3 & 11,1 & 27 & $0,02-0,41$ & \\
\hline \multicolumn{8}{|l|}{ Frek. Iama tidur: } \\
\hline$<6$ jam & 10 & 43,5 & 13 & 56,5 & 23 & 0,09 & 0,002 \\
\hline 6-8 jam & 24 & 88,9 & 3 & 11,1 & 27 & $0,02-0,41$ & \\
\hline \multicolumn{8}{|l|}{ Riw. sakit dahulu : } \\
\hline $\mathrm{Ya}$ & 21 & 72,4 & 8 & 27,6 & 29 & 1,61 & 0,632 \\
\hline Tidak & 13 & 61,9 & 8 & 38,1 & 21 & $0,48-5,36$ & \\
\hline \multicolumn{8}{|l|}{ Frek. Riw. Sakit : } \\
\hline Setiap bln & 18 & 85,7 & 3 & 14,3 & 21 & 10,00 & 0,033 \\
\hline Tdk setiap bln & 3 & 37,5 & 5 & 62,5 & 8 & $1,52-65,67$ & \\
\hline
\end{tabular}

Kebiasaan tidur malam nilai $\mathrm{OR}=0,09$, artinya mahasiswa yang memiliki kebiasaan tidur malam lebih dari jam 9 mempunyai peluang sakit 0,09 kali dibandingkan dengan yang memiliki kebiasaan tidur jam 9; Frekuensi lamanya tidur malam nilai $\mathrm{OR}=0,09$, artinya mahasiswa yang memiliki lamanya tidur malam kurang dari 6 jam mempunyai peluang sakit 0,09 kali dibandingkan dengan yang memiliki lama tidur malam 6 8 jam dan riwayat sakit dahulu nilai $\mathrm{OR}=1,61$, artinya mahasiswa yang memiliki riwayat dakit dahulu mempunyai peluang sakit 1,61 kali dibandingkan dengan yang tidak memiliki riwayat sakit dahulu serta antara frekuensi riwayat sakit dahulu dengan kejadian sakit sekarang. diperoleh juga nilai $\mathrm{OR}=10,00$, artinya mahasiswa yang memiliki riwayat sakit dahulu dengan frekuensi sakit setiap bulan mempunyai peluang sakit 10,00 kali dibandingkan dengan yang memiliki riwayat sakit dahulu dengan frekuensi sakit tidak setiap bulan.

\section{PEMBAHASAN}

Pembahasan pada penelitian ini menggunakan pendekatan model segitiga epidemiologi (Triad Epidemiological) yang menggambarkan interaksi tiga komponen penyebab penyakit yaitu manusia (Host), Penyebab (Agent) dan lingkungan (Environment) seperti yang tercantum dalam tinjauan teori pada bab II yang dibandingkan dengan hasil penelitian.

Kejadian sakit sebagai variabel terikat banyak dipengaruhi oleh determinan lain seperti yang telah dibahas dalam kerangka teori dan kerangka konsep. Dalam penelitian ini masih ada variabel-variabel bebas yang tidak diikutsertakan, seperti variabel agen penyakit, latar belakang mahasiswa, status gizi, perilaku, lingkungan dan lainnya. 
Gambaran yang didapatkan pada penelitian ini, diketahui bahwa kejadian sakit setiap bulan yang terjadi selama tiga bulan terakhir pada mahasiswa tingkat I Akper Pemkab Garut tertinggi pada perempuan $(83,3 \%)$ dan setelah dilakukan uji statistik didapatkan nilai $p$-Value sebesar 0,011. Dari nilai hasil uji tersebut terbukti bahwa jenis kelamin berhubungan dengan kejadian sakit pada mahasiswa Akper Pemkab Garut. Hal ini sesuai dengan laporan SKRT 2012 tentang studi morbiditas dan disabilitas, dimana pada hasil laporan tersebut menyatakan angka kesakitan penduduk pada perempuan lebih tinggi dibandingkan dengan kesakitan pada laki-laki.

Menurut penulis, bahwa angka kesakitan pada perempuan sangat tinggi diakibatkan adanya perbedaan tentang upaya mekanisme pertahan tubuh antara laki-laki dan perempuan dalam menghadapi stressor, seperti yang dikemukakan oleh Asmadi 2005 bahwa laki-laki lebih agresif baik secara fisik ataupun secara verbal, sedangkan perempuan berdasarkan kodrat biologisnya kurang agresif sehingga menekan impulsimpuls tidak bersahabat karena takut pada resikonya.

Dengan kata lain terlihat bahwa perempuan akan lebih cepat frustasi karena terlalu banyak menyimpan beban stres yang akan berpengaruh terhadap sistem fisiologi dari tubuh individu yang mengakibatkan terganggunya keseimbangan terutama pada sistem saraf dan otak sebagai sentral pengaturan fungsi tubuh yang normal sehingga akan merangsang sistem endokrin dalam uapaya mempertahankan homeostasis.

Pendapat lain yang sama adalah menurut Peter dalam Asmadi, 2005 yang menyatakan bahwa: "Beberapa penyebab penting dari penyakit pada manusia adalah agen infeksi, trauma mekanis, bahan kimia beracun, radiasi, suhu yang ekstrim, masalah gizi dan stres psikologik". Penyakit sesungguhnya merupakan bagian dari hidup indvidu yang sakit, oleh karena itu perlu dipertimbangkan mekanisme respon intrinsik dari individu dan semua proses biologis. Selain itu jenis kelamin juga merupakan faktor yang perlu dipertimbangkan dalam patogenesis penyakit sebab sifat anatomik hospes dan mekanisme fisiologis serta cara respon ditentukan oleh informasi genetik.

Pada penelitian ini, selain menemukan adanya hubungan kejadian sakit dengan jenis kelamin juga menemukan adanya variabel faktor manusia (Host) lain yang berhubungan dengan kejadian sakit yaitu pola makan ( $p$-Value 0,003 ), aktifitas olah raga ( $p$-Value 0,009$)$, frekuensi melakukan olah raga ( $p$-Value 0,034$)$, kebiasaan tidur malam ( $p$-Value 0,002), dan frekuensi lamanya tidur ( $p$-Value 0,002) dari mahasiwa tingkat I yang mengalami sakit pada tiga bulan terakhir yang teregistrasi mengikuti pendidikan di Akper Pemkab Garut.

Hal ini diakibatkan oleh karena tingkat I merupakan tingkat awal masa perubahan jenjang pendidikan dari masa SLTA menginjak ke masa pendidikan diploma yang jelas sangat berbeda tentang proses dan strategi belajar mengajarnya, sehingga memungkinkan mahasiswa kurang siap untuk menghadapi perubahan tersebut yang dapat mengakibatkan stres psikologik yang berpengaruh pada sistem homeostasis fisiologis tubuh karena mahasiswa belum atau kurangnya pengalaman untuk beradaptasi terhadap perubahan tersebut.

Tingkatan kelas sangat berpengaruh terhadap mekanisme pertahan tubuh dalam mengatasi stres, seperti yang dikemukakan oleh peneliti lain yaitu Rosidin (2004) yang menyatakan bahwa tingkatan kelas menunjukan variasi lamanya mengikuti pendidikan di Akper sehingga mahasiswa tingkat III mempunyai kemampuan beradaptasi dengan lingkungan akan lebih baik dari mahasiswa tingkat I. demikian pula dengan tingkat II akan mempunyai kemampuan beradaptasi lebih baik dari tingkat I. Sedangkan antara tingkat II dan tingkat III relatif tidak berbeda 
kemampuan adaptasinya karena waktu menjalani proses belajar di Akper tidak jauh berbeda.

Peneliti lainnya yang mendukung yaitu Haruman (2005) bahwa mahasiswa seringkali merasakan bahwa pelajaran yang diterima di Akademi Keperawatan sangat asing bagi dirinya dan jauh berbeda dengan apa yang pernah diterima sewaktu di bangku SLTA. Disini timbul permasalahan kesulitan belajar baik yang menyangkut pengetahuan, sikap, keterampilan maupun kondisi kesehatan, sehingga mahasiswa sulit mengatur pola aktivitas olah raga, mengalami gangguan kebiasaan tidur malam yang berdampak pada kurangnya jam tidur malam serta perubahan pola makan.

Menurut peneliti, bahwa hal tersebut diatas berpengaruh terhadap perubahanperubahan yang terjadi sehingga akan mempengaruhi tingkat kerentanan terhadap penyakit dan meningkatkan penyebaran suatu penyakit. Dari perilaku individu, kecenderungan yang terjadi adalah perubahan pola makan dan kualitas makanan yang tidak teratur dimana segala jenis dan bentuk makanan yang tersedia dengan berbagai macam kemasan, sehingga mahasiswa mengkonsumsinya tanpa melihat kecukupan gizi yang diperlukan dan menganggap hal biasa sebagai gaya hidup yang modern dan mengikuti zaman. Sehingga dari perubahan gaya hidup tersebut akan menimbulkan menurunya daya tahan tubuh akibat tubuh kekurangan zat gizi yang diperlukan untuk melakukan aktivitas olah raga dan gangguan kebiasaan tidur, yang pada akhirnya akan menimbulkan kerentanan tubuh terhadap suatu penyakit.

Untuk membantu proses adaptasi dari mahasiswa tersebut perlu adanya peran pembimbing akademik sebagai fasilitator dalam mengatasi berbagai permasalahan yang dihadapi mahasiswa, mulai dari kegiatan proses pendidikan sampai kondisi keadaan biopsikososial mahasiswa selama mengikuti proses pendidikan di Akademi Keperawatan. Salah satu upayanya dengan pendekatan promotif dan preventif tanpa mengabaikan upaya kuratif dan rehabilitatif. Upaya-upaya tersebut dapat dilakukan dengan menggunakan fasilitas sarana pelayanan kesehatan yang terdekat sebagai upaya deteksi dini terhadap gangguan kesehatan mahasiswa, dapat berupa balai kesehatan, balai pengobatan maupun klinik kesehatan.

\section{KESIMPULAN}

Terdapat hubungan antara jenis kelamin dengan kejadian sakit. Terdapat hubungan antara pola makan dengan kejadian sakit. Terdapat hubungan antara aktivitas melakukan olah raga dengan kejadian sakit. Terdapat hubungan antara frekuensi melakukan olah raga dengan kejadian sakit. Terdapat hubungan antara kebiasaan tidur malam dengan kejadian sakit. Terdapat hubungan antara frekuensi lamanya tidur malam dengan kejadian sakit. Tidak terdapat hubungan antara riwayat sakit dahulu dengan kejadian sakit. Terdapat hubungan antara frekuensi riwayat sakit dahulu dengan kejadian sakit pada mahasiswa tingkat satu Akper Pemkab Garut.

\section{SARAN}

Perlunya penegasan tentang peningkatan peran pembimbing akademik dalam memberikan bimbingan dan penyuluhan dalam mengatasi permasalahan mahasiswa terutama masalah kesehatan yang secara langsung atau tidak langsung akan mempengaruhi proses pembelajaran selama mengikuti pendidikan di Akper Pemkab Garut.

Perlunya kebijakan tentang upaya kerjasama dengan dinas Kesehatan Kabupaten untuk penataan sarana dan prasarana yang menunjang pelayanan kesehatan mahasiswa berupa Balai Kesehatan Mahasiswa untuk menemukan dan mengatasi permasalahan kesehatan sedini mungkin sehingga tidak mengganggu terhadap proses belajar mengajar secara keseluruhan. 
Perlu dilakukan penelitian lebih lanjut tentang variabel-variabel lain yang berhubungan dengan kesakitan diluar variabel yang diteliti, misalnya variabel agen penyakit, latar belakang mahasiswa, status gizi, dan variabel lingkungan, agar dapat menemukan lebih lanjut tingkat hubungan dari variabel-variabel epidemiologi lainya.

\section{DAFTAR PUSTAKA}

Akper Pemkab Garut, (2016). Buku

Panduan Akademi Keperawatan

Pemerintah Kabupaten Garut Tahun.

Apriningsih, (2006). Epidemiologi Dan

Biostatistik: Panduan Studi, EGC, Jakarta

Arikunto, (2006). Prosedur Penelitian Suatu Pendekatan Praktik,Rineka Cipta, Jakarta

Asmadi, (2005). Konsep Sakit Dan Kesakitan, UMM Press, Malang

Bustan, M.N., (2007). Pengantar Epidemiologi, Rineka Cipta, Jakarta

Chandra, B., (2007). Pengantar Statistik Kesehatan, EGC, Jakarta

Depkes RI, (2012). Survei Kesehatan Nasional : Laporan SKRT Studi Morbiditas dan Disabilitas, Jakarta

Efendy, (2009). Keperawatan Kesehatan Komunitas: Teori Dan Praktik Dalam Keperawatan, Salemba Medika, Jakarta

Hamidi, (2010). Metode Penelitian Dan Teori Komunikasi, UMM Press, Malang

Handayani, (2006). Konsep Dan Teknik Penelitian Gender, UMM Press, Malang

Kodim, N., (2005). Himpunan Bahan Kuliah Epidemiologi Penyakit Tidak Menular, FKMUI

Mubarak, (2012). Ilmu Kesehatan Masyarakat: Konsep Dan Aplikasi, Salemba Medika, Jakarta

Nasrullah, (2006). Pengantar Biostatistik Edisi Kedua, Gadjah Mada University Press, Yogyakarta otoatmodjo, S., (2006). Metodologi Penelitian Kesehatan, Rineka Cipta, Jakarta

Sutanto P.H., (2005). Analisa Data, FKMUI, Jakarta. 